\title{
Electricity from Wind for Off-Grid Applications in Bangladesh: A Techno-Economic Assessment
}

\author{
Md. Mustafizur Rahmana,**, Md Abdullah Hil Bakya, A.K.M.Sadrul Islama \\ ${ }^{a}$ Department of Mechanical and Chemical Engineering, Islamic University of Technology, Board Bazar, Gazipur 1704, Bangladesh
}

\begin{abstract}
Global GHG (greenhouse gas) emissions are increasing substantially and electricity sector is one of the key contributors to the world's total GHG emissions. GHG emissions cause ozone layer depletion and global warming. Different policy regulation agencies are adopting regulations to reduce GHG emissions in various sectors. People already have started power generation from cleaner sources. Renewable energy sources can provide cleaner electricity. Bangladesh is a densely populated country and most of the country's electricity is produced from natural gas and coal. The Bangladesh government has set a goal to utilize renewable energy for the production of $10 \%$ of its electricity by the year 2020 . Bangladesh has a lot of isolated coastal areas which are not connected to the national grid which can be electrified by using abundant wind energy. In this study a technoeconomic analysis has been conducted for an off-grid island of Bangladesh. The analysis was conducted by developing a data intensive model that calculates the generation cost of electricity from wind energy. The model also estimates the capital cost of the system. The model shows that electricity can be produced from wind energy at a cost of $\$ 0.57 / \mathrm{kWh}$. The system's capital cost was calculated to be $\$ 63,550.16$.
\end{abstract}

Keywords: GHG emission, cost of electricity, off-grid, wind energy, electricity generation.

Article History: Received October $15^{\text {th }}$ 2016; Received in revised form January 26 ${ }^{\text {th }} 2017$; Accepted February $4^{\text {th }} 2017$; Available online How to Cite This Article: Rahman, M.M., Baky, M.A.H, and Islam, A.K.M.S. (2017) Electricity from Wind for Off-Grid Applications in Bangladesh: A Techno-Economic Assessment. International Journal of Renewable Energy Develeopment, 6(1), 55-64.

http://dx.doi.org/10.14710/ijred.6.1.55-64

\section{Introduction}

Environmental concerns and international agreements to reduce the atmosphere's greenhouse gases and minimizing dependency on the fossil based non-renewable fuels are the most important reasons behind the increased interest in renewable energy resources in recent years (Khan, Hawboldt, \& Iqbal, 2005 ). About $60 \%$ of the total greenhouse gases emitted in the environment is caused by energy generation from fossil fuels (IEA 2009). United States being the largest consumer (almost $50 \%$ of the world's total energy consumption) releases $22 \%$ of the carbon-di-oxide by combustion of fossil fuels (Pimentel et al., 2002; Turner, 1999). The reserves of fossil fuels are also reducing at an alarming rate at the same time. For example, USA having consumed $82-88 \%$ of the oil reserves, now imports $60 \%$ of its oil and it is predicted that within 20 years they will have to import $80-90 \%$ of its oil (American Petroleum Institute. 1999. Basic Petroleum Data Book. Washington (DC): API). Same is the scenario for most of the countries around the globe. Therefore, many countries are adopting renewable energy in place of conventional fuels for electricity generation. The United Nations expects $30 \%$ of the world's need of energy to be covered by renewables by 2030 and $45 \%$ by 2050 (IEA. Key issues in developing renewable. Paris: International Energy Agency, 1997). As of 2014 the world's power generation capacity from the renewable sources was 1712.20 GW ("REN21. Renewables 2015 Global Status Report,"). A comparison of source wise capacity of power generation from different renewable sources in 2004 and 2014 is shown in Table 1. The growth of power generation from solar $\mathrm{PV}$ and wind was tremendous (see Table 1).

However, in Bangladesh only 3.45\% of 12,262 MW of total installed capacity of electricity generation is obtained from renewable sources as of April 2016, whereas $62 \%$ of the total capacity comes from natural gas ("Bangladesh Power Development Board,").

* Corresponding author: mdmustaf@ualberta.ca 
Citation: Rahman, M.M., Baky, M.A.H., Islam A.K.M.S. (2017), Electricity from Wind for Off-Grid Applications in Bangladesh: A Techno-Economic Assessment. Int. Journal of Renewable Energy Development, 6(1), 55-64, doi.org/10.14710/ijred.6.1.55-64

$\mathrm{P}$ a g e $\mid 56$

Tabel 1

The world's power generation capacity from renewable sources. Source: Ref. ("REN21. Renewables 2015 Global Status Report,")

\begin{tabular}{lcc}
\hline Renewable source & $\begin{array}{c}\mathbf{2 0 0 4} \\
\text { (GW) }\end{array}$ & $\begin{array}{c}\mathbf{2 0 1 4} \\
\text { (GW) }\end{array}$ \\
\hline Hydro power & 715 & 1055 \\
Bio power & $<36$ & 93 \\
Geothermal power & 8.9 & 12.8 \\
Solar PV & 2.6 & 177 \\
Concentrating solar thermal power & 0.4 & 4.4 \\
Wind power & 48 & 370 \\
\hline
\end{tabular}

The breakdown of the installed power generation of Bangladesh by source is shown in Figure 1. By 2020 the electricity generation from renewable sources in Bangladesh is expected to be $10 \%$ of the total capacity although the expected 5\% within 2015 is not achieved. Per capita generation of electricity in Bangladesh is very low, which is about only $258 \mathrm{kWh}$ /year ("The world Bank,"). Only $53 \%$ of the population is taken under electrification. To deal with the increasing demand of electricity several measures to harness energy from renewable sources are being taken by the government and several organizations including IDCOL (Infrastructure Development Company Limited), Grameen Shakti (which is a sister organization of the Grameen Bank), etc. These organizations mainly work with propagation of renewable energy technologies in Bangladesh. The government has launched a project to produce $500 \mathrm{MW}$ of electricity from solar power, whereas IDCOL is working to install 6 million solar home systems (SHSs) by 2017 ("IDCOL, Infrastructure Development Company Limited," ; "Power Division. Government of The People's Republic of Bangladesh,"). The current power generation scenario of Bangladesh from renewable sources is shown in Table 2 .

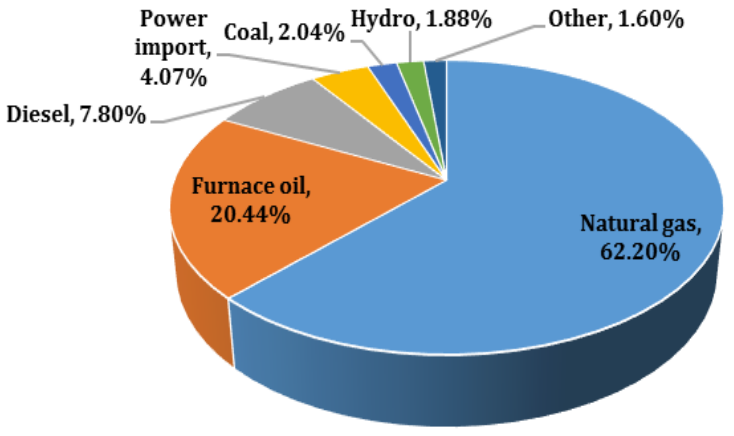

Figure 1. Breakdown of installed electricity generation capacity of Bangladesh by source. Source: Ref. ("Bangladesh Power Development Board,")
Table 2

Installed renewable energy technologies in Bangladesh. Source: (Sustainable \& renewable energy energy development authority (SREDA))

\begin{tabular}{cccc}
\hline $\begin{array}{c}\text { Renewable } \\
\text { energy technology }\end{array}$ & Off-grid (MW) & On-grid (MW) & Total (MW) \\
\hline Biogas to electricity & 5 & - & $\mathbf{5}$ \\
Biomass to electricity & 1 & - & $\mathbf{1}$ \\
Hydro & - & 230 & $\mathbf{2 3 0}$ \\
Solar PV & 184 & 1 & $\mathbf{1 8 5}$ \\
Wind & 1 & 0.9 & $\mathbf{1 . 9}$ \\
Total & $\mathbf{1 9 1}$ & $\mathbf{2 3 2}$ & $\mathbf{4 2 3}$ \\
\hline
\end{tabular}

Although wind energy is not so promising as other renewable energy systems since it is limited to rivers sides, coastal areas, offshore islands and other inland open areas with strong wind regime but wind has the lowest GHG emissions, with only around $25 \mathrm{~g}$ $\mathrm{CO}_{2} \mathrm{eq} / \mathrm{kWh}$ and is a fast growing renewable energy technology (Evans, Strezov, \& Evans, 2009). From 1980 to 2005 the cost of electricity generated from wind has been reduced from 20 eurocents to 3.7 eurocents (Mathew, 2006). The reduction in the price resulted in increased interest in wind energy systems and it is assumed that by 2030 the installed capacity of wind energy will be 100,000 MW in Europe and by 2020 worldwide capacity of wind energy will be 180-474 GW (Akpinar \& Akpinar, 2006). The global wind power generation capacity has been increasing substantially. The electricity generation from wind is increased by $118 \%$ from 2010 to 2015 . The global wind power addition was $51 \mathrm{GW}$ in 2014 and $63 \mathrm{GW}$ in 2015 and reached a total capacity of $432 \mathrm{GW}$. The global wind power generation capacity from 2000-2015 is shown in Figure 2.

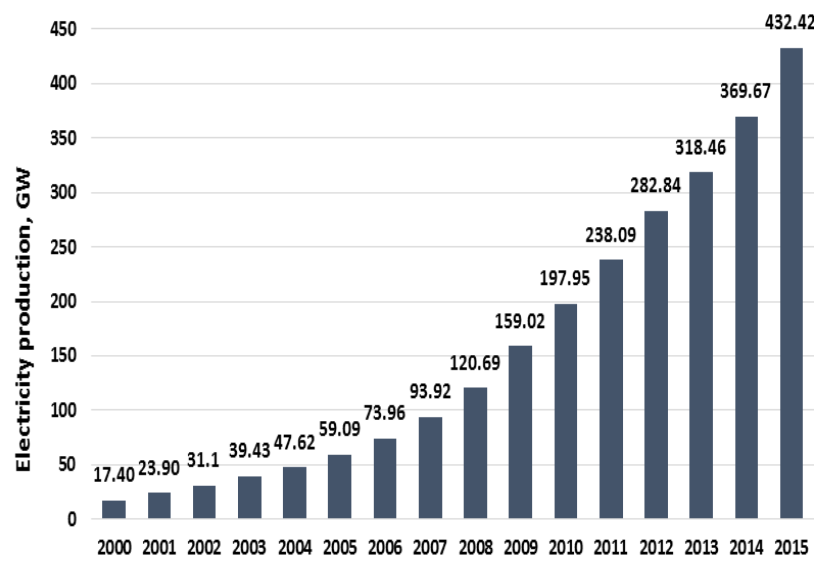

Figure 2. Global cumulative installed wind capacity from 2000 to 2015. Source: Ref. ("GWEC. Global Wind Energy Council,")

In Bangladesh two wind plants have been installed of $900 \mathrm{~kW}$ and $1000 \mathrm{~kW}$ at Sonagazi and at Kutubdia Island, respectively ("Bangladesh Power Development Board,"). But due to natural calamities these plants are left unutilized. Anyway recently the government has taken steps to recover these plants and in addition, a 15 
MW wind power plant is under construction across the coastal region of Bangladesh. Bangladesh Power Development Board (BPDB) has another 50-200 MW wind energy project, which is under planning (Bangladesh Power Development Board).

Several studies have conducted the techno economics of stand-alone wind energy systems. Celik (Celik, 2007) analysed the technical and economic assessments of wind energy in southern Turkey. The author found that the lowest cost of electricity with the nominal power of $500 \mathrm{~kW}$ was $\$ 0.15 / \mathrm{kWh}$ and it was very close to Turkey's electricity production from conventional sources which is $\$ 0.13 / \mathrm{kWh}$. Chong et al. (Chong, Naghavi, Poh, Mahlia, \& Pan, 2011) on the other hand introduced solar with wind energy and suggested a system to supply power to a high rise building which utilizes a power-augmentation guide vane to channel wind to the turbine. The techno-economic analysis of this system estimates the energy saved by the system to be 195 MWh/year. PV, hydro and diesel were introduced with wind energy in HOMER software by Sopian et al. (Sopian, Ali, Alghoul, Zaharim, \& Ahmad, 2009 ) to simulate the cost of production of energy. The authors suggest that it is possible to minimize the cost by $50 \%$ with maximum demand load capacity. Ahmed et al. (Ahmed, Miyatake, \& Al-Othman, 2008) designed a system consisting of variable speed wind turbine, fuel cell and solar photovoltaic to supply continuous power to a residential building where wind and photovoltaic were the main energy sources and fuel cell was the backup energy source. The system was designed to power a $2 \mathrm{~kW} / 150 \mathrm{~V}$ load continuously for the whole year and the result shows that even if there is no wind or sunlight the system provides full power to the load. $\mathrm{Li}$ et al. (Li et al., 2013) studied a photovoltaic (PV)/wind/battery hybrid power system and found that the system reduces the net cost by $9 \%$ and $11 \%$ compared to photovoltaic/battery and wind/battery system, respectively. In the system they have used $5 \mathrm{~kW}$ of PV arrays, one $2.5 \mathrm{~kW}$ wind turbine and 8 batteries each of $6.94 \mathrm{kWh}$. Muralikrishna and Lakshminarayana (Muralikrishna \& Lakshminarayana, 2008) found the energy cost for PV-wind hybrid system to be less than the stand-alone PV or wind system all the time. There have been number of studies that design hybrid renewable energy systems and estimate the cost of electricity for various regions around the globe (Abdulkarim, 2004; Adaramola, Agelin-Chaab, \& Paul, 2014; Chandel, Agrawal, Mathur, \& Mathur, 2014; Fadaeenejad, Radzi, AbKadir, \& Hizam, 2014; Ghasemi, Asrari, Zarif, \& Abdelwahed, 2013; Kusakana \& Vermaak, 2013; Ngan \& Tan, 2012; Md Mustafizur Rahman, Khan, Ullah, Zhang, \& Kumar, 2016; Rehman \& Al-Hadhrami, 2010; Rohani \& Nour, 2014). The cost of electricity depends on various factors such as resource availability (e.g. solar insolation, wind speed, etc.), price of components, project interest rate, lifetime of projects, etc. Islam et al. (Islam, Rahman, Mondal, \& Alam, 2012) analysed the techno-economic aspect of a hybrid system for Saint Martin's Island, Bangladesh. The authors found the COE (cost of electricity) to be $\$ 0.345 / \mathrm{kWh}$. Salehin et al. (Salehin, Rahman, \& Islam, 2015) designed a solar PV-diesel generator system for an off-grid location in Bangladesh with a COE of $\$ 0.461 / \mathrm{kWh}$. Rahman et al. (Md. Mustafizur Rahman, Islam, Salehin, \& Al-Matin, 2016) performed a techno-economic analysis of a stand-alone PV system for application in an isolated community in Bangladesh. The COE was calculated to be $\$ 0.72 / \mathrm{kWh}$.

Since the wind energy field in Bangladesh has got less attention compared to solar, hydro and biomass, there is lack of information regarding the parameters related to the economics of power generation from wind energy. Fewer studies have conducted the technoeconomic analysis of hybrid renewable energy systems (different combinations of solar PV-wind-diesel, etc.) and stand-alone solar PV systems for isolated communities in Bangladesh but assessment of wind energy for power generation is very limited. There have been studies on techno-economic assessment of wind power in various countries but these are not applicable for Bangladesh as designing a renewable energy system and estimating the cost of electricity are very much location-specific. The main objectives of this research are (i) to design a wind energy system for electricity generation for an isolated off-grid community in Saint Martin's Island, Bangladesh and (ii) to conduct a techno-economic assessment of the designed system by developing an excel-based bottom-up engineering model that can estimate the capital cost and the electricity generation cost. The proposed power generation system using wind energy will replace the existing diesel generator system for the selected location. The present study also shows how much GHG emissions could be reduced if the diesel-fueled generators are replaced by the wind turbines. An analysis is also performed to find out the sensitivity of the most influential inputs that can affect the results.

\section{Methodology}

This study carries out a techno-economic assessment (TEA) of electricity generation from wind energy resource. Firstly, a stand-alone wind turbine system was designed to fulfill the demand of electricity of a community consisting 50 households in the Saint Martin's Island, Bangladesh. Then a TEA was conducted to estimate the capital cost and the COE of the system. The techno-economic assessment was conducted by developing an excel-based data-intensive technical model. The model considers all the components of the wind energy system for power generation. The system boundary used for this study is depicted in Figure 3. The components of wind power generation system includes one or more wind turbine(s), a turbine controller for converting the AC current produced by the wind 
turbine(s) to DC current which is to be stored in the bank of batteries.

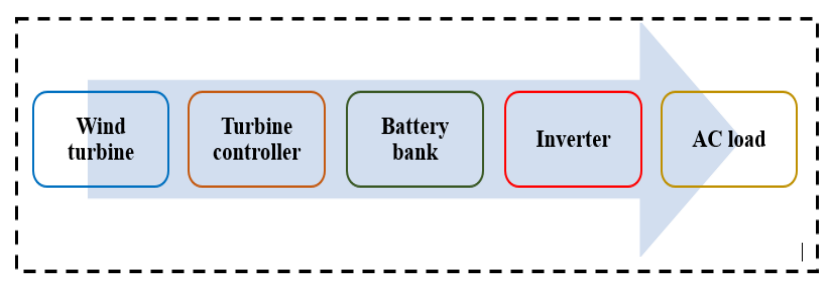

System boundary

Figure 3 System boundary used for this study

The inverter alters the direct current (DC) coming out of the battery bank to alternating current (AC). This research also includes the component's installation and maintenance costs and cost of civil works within its system boundary. The transmission system (e.g. copper cables and pillars to carry the cables) were not considered within the system boundary. It was assumed that the existing transmission system will be used for the proposed power generation system from wind. Figure 4 represents the methodology used for estimating the cost parameters related to the production of electricity from wind energy. The functional unit was considered as $1 \mathrm{kWh}$ AC electricity and all the cost numbers are in 2015 US dollars unless otherwise mentioned.

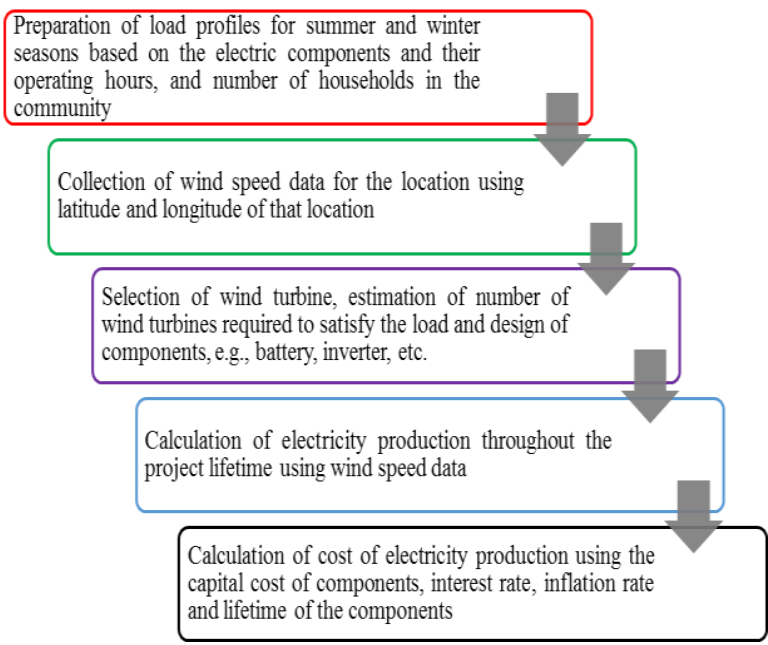

Figure 4. Modelling methodology developed for this study

The location, Saint Martin's Island was selected due to the availability of wind energy throughout the year. The electric load demand was estimated for summer and winter seasons separately based on the total number of electric equipment per household and their operating hours and the total number of households in the community. Wind data throughout the year were collected from NASA surface meteorology website ("Surface meteorology and solar energy,") using the location's latitude and longitude values. Then sizing of all the components (e.g. wind turbine, battery, inverter, etc.) was done to meet the load demand. The electricity production was estimated throughout the project life depending upon the data of wind speed of the location. Finally, the cost numbers (e.g. capital cost and COE) were calculated using the capital cost of each component and their useful life, interest rate and inflation rate.

\subsection{Site selection and load calculation \\ 2.1.1 Site description: Saint Martin's Island}

The Saint Martin's Island was selected for the analysis as this place has significant wind energy potential for power generation which can replace the existing power generation method (i.e. diesel generators). The island is situated in the north-eastern side of the Bay of Bengal and from cox's bazar-saint Martin peninsula almost $9 \mathrm{~km}$ to south (Islam et al., 2012). The geographical coordinates of the island are $20.63{ }^{\circ} \mathrm{N}$ and $92.32^{\circ} \mathrm{E}$ (Islam et al., 2012). The total population of the island is around 7500 and fishing is their main profession ("Saint Martin Coral Island, Bangladesh,"). The total area of the island is $8 \mathrm{~km}^{2}$ (Ahammed, Hossain, Abedin, \& Khaleque, 2016). An aerial view of the island is depicted in Figure 5 . The island is separated from the national grid of Bangladesh. The residents of the island produce their own electricity using diesel generators and the fuel for the generators is transported through ships from the main land of Bangladesh to the island which raises the cost of fuel and in turns cost of electricity is increased. On the other hand burning diesel releases greenhouse (GHG) gases into the atmosphere which causes global warming. Saint Martin's Island has good wind energy potential that can be used to generate electricity using wind energy.

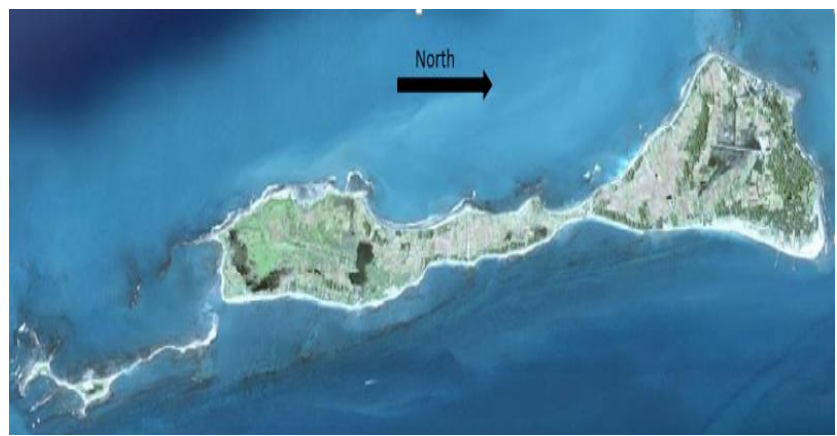

Figure 5. An aerial view of the Saint Martin's Island, Bangladesh. Adapted from ref. (Islam et al., 2012)

\subsubsection{Estimation of electric load}

Usually the load profiles of rural communities are very simple. Electricity consumption in rural communities is very low compared to urban communities. A typical household in rural communities uses few LED bulbs for lighting, a small television for 
entertainment and one or more ceiling fans for cooling purpose (Md. Mustafizur Rahman et al., 2016). In this study, 5 LED bulbs ( $3 \mathrm{~W}$ each), an LCD television (18 W) and 2 ceiling fans ( $24 \mathrm{~W}$ each) were considered. Fans are only used in the summer season. The daily operating hours for lights, television and fans were considered to be 8 hours, 6 hours and 10 hours, respectively. Two different load profiles for a hypothetical model community of fifty houses were created for winter (November-March) and summer (April-October) seasons. The average electricity consumption for the community was $11.4 \mathrm{kWh} /$ day and $35.4 \mathrm{kWh} /$ day for winter and summer, respectively. The peak load in summer season was estimated as $4.05 \mathrm{~kW}$. The total load throughout the year was found to be 9.144 MWh.

\subsection{Assessment of wind energy and electricity generation}

The wind speed data were obtained from NASA surface meteorology and solar energy website ("Surface meteorology and solar energy,") using the latitude and longitude of the island. Figure 6 represents the monthly averaged wind speed data at $50 \mathrm{~m}$ height for Saint Martin's Island. Wind speed is high in June, July and August. In December the wind speed was minimum $(3.64 \mathrm{~m} / \mathrm{s})$ and in July it was maximum $(7.43 \mathrm{~m} / \mathrm{s})$. The yearly average wind speed was $4.85 \mathrm{~m} / \mathrm{s}$.

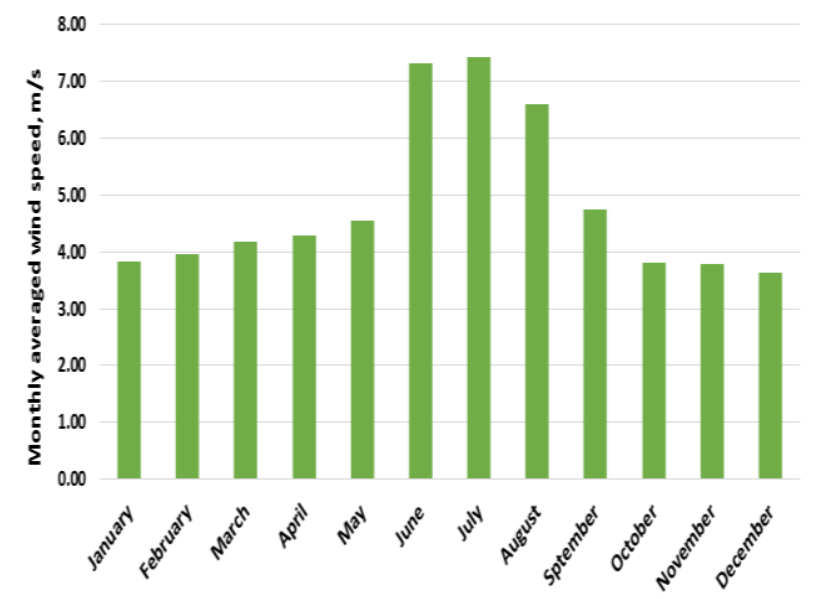

Fig. 6 Wind speed variation throughout the year in Saint Martin's Island, Bangladesh

Any place does not get the same wind speed round the clock throughout the year. So to find out the mean power from a turbine it is important to find the probability distribution of wind speed (Md Mustafizur Rahman et al., 2016). The Weibull distribution expression is shown in (Eq 1) (Bhuiyan, Islam, \& Alam, 2013) which shows a good fit to wind data. In (Eq 1), f (V) is probability density function, (k) is the Weibull shape factor, (c) is the scale factor and (V) is the wind velocity.

$$
f(V)=\frac{k}{c}\left(\frac{V}{C}\right)^{k-1} e^{-\left(\frac{V}{c}\right)^{k}}
$$

Here, $\mathrm{k}$ and $\mathrm{c}$ were calculated from the monthly mean wind velocity for the selected location using the Web Based Wind Resource Assessment (WEA) Tool (Bhuiyan et al., 2013). Given the mean wind velocity of $4.85 \mathrm{~m} / \mathrm{s}$, a wind turbine was selected for this research based on the cut-in speed and rated power: a $3.2 \mathrm{~kW}$ wind turbine of model W175 manufactured by Unitron South West Windpower, USA (Nouni, Mullick, \& Kandpal, 2007). A hub height of $50 \mathrm{~m}$ was assumed in this study (Md Mustafizur Rahman et al., 2016; Verma, Raj, Kumar, Ghandehariun, \& Kumar, 2015). The cut-in speed and the rated speed of the turbine are $2.5 \mathrm{~m} / \mathrm{s}$ and $11 \mathrm{~m} / \mathrm{s}$, respectively. All the other specifications of the turbine is presented in Table 3. The WEA tool was used to estimate the electricity production and the capacity factor using shape factor, scale factor, cut-in speed, cutout speed, rated speed, ideal velocity power proportionality and total operating hours (8760 hours) in a year.

Table 3

Technical specifications of the wind turbine selected in this research

\begin{tabular}{lcc}
\hline Parameter & Value & Comment/source \\
\hline Size of the turbine, kW & 3.2 & (Nouni et al., 2007) \\
Rotor diameter, m & 4.65 & (Nouni et al., 2007) \\
Rotor swept area, m² & 16.98 & (Nouni et al., 2007) \\
Cut in wind speed, m/s & 2.5 & (Nouni et al., 2007) \\
Cut out wind speed, & 21.0 & (Nouni et al., 2007) \\
m/s & & \\
Rated wind speed, m/s & 11.0 & (Nouni et al., 2007) \\
Hub height, m & 50 & Wind speed data are \\
& & available for 50 m height. \\
& & Most of the studies work with \\
& 50 m hub height (Md \\
& & Mustafizur Rahman et al., \\
& & 2016; Verma et al., 2015) \\
\hline
\end{tabular}

\subsection{Design of the power generation system}

The system components are wind turbine, turbine controller, inverter and battery bank (see Figure 3). These components were designed using the fundamental engineering principles to meet the load demand of $9.144 \mathrm{MWh} / \mathrm{year}$. The number of wind turbines was estimated using the load demand during summer to avoid any capacity shortage and the effective energy generated by a $3.2 \mathrm{~kW}$ wind turbine. The turbine controller converts the AC output from the turbine to DC input to the battery storage system. Wind speed is not continuous round the clock throughout the year. There are no or less windy days when power generation 
from wind is not possible. So, there is a necessity to store the electricity for sufficient time period without adequate electricity supply. The battery capacity was estimated using (Eq 2) ("Leonoics,") where the total battery capacity, (BC) is in Ah, the peak load demand during summer, (L), is in Wh/day, depth of discharge, (DD) is in \%, number of days of autonomy, (D), is in days, charging efficiency, $\left(\eta_{c}\right)$ is in $\%$, the nominal voltage of each battery (V) is in volts.

$\mathrm{BC}=(\mathrm{L} \times \mathrm{D}) /\left(\mathrm{DOD} \times \eta_{\mathrm{c}} \times \mathrm{V}\right)$

In this research, (DD), (D) and ( $\left.\eta_{c}\right)$ were assumed as 80\% (Verma et al., 2015), 2 days and 85\% (Md. Mustafizur Rahman et al., 2016), respectively. $130 \mathrm{Ah}$ capacity and $12 \mathrm{~V}$ batteries were selected for the analysis due to their availability in the local markets (Md. Mustafizur Rahman et al., 2016). To convert the DC electricity coming from the battery bank to AC electricity to be used in the appliances an inverter is required. An inverter is designed based on the maximum demand of the system. The peak load of the system was estimated to be $4.05 \mathrm{~kW}$. For designing the inverter a safety factor of $30 \%$ was used (Md. Mustafizur Rahman et al., 2016). A $5.27 \mathrm{~kW}$ inverter is required to safely operate the system.

\subsection{Techno-economic assessment model}

A techno-economic model was built to estimate the COE of the system. The year 2015 was selected as the base year and all the cost numbers are based on 2015 US dollars unless otherwise stated. The capital cost consists of costs of the turbine with tower and controller, battery bank, inverter, and costs of installation and civil works. The capital costs of the system components were amortized with an interest rate of $10 \%$ (Zubair, Tanvir, \& Hasan, 2012) over the useful life of each component. The project lifetime was assumed 20 years (Ajayi, Ohijeagbon, Aasa, \& Omotosho, 2014; Dursun, Gokcol, Umut, Ucar, \& Kocabey, 2013; Fleck \& Huot, 2009). The cost data that are not in 2015 USD were inflated using an inflation rate of $7.30 \%$ ("Bangladesh Bank,"). The conversion rate from USD to Bangladeshi Taka (BDT) was considered to be 77 (Md. Mustafizur Rahman et al., 2016). The yearly maintenance cost was considered $2.0 \%$ of the capital cost (Md. Mustafizur Rahman et al., 2016). The technical parameters and assumptions used to develop the model are furnished in Table 4.

The COE was evaluated from the system's total annual cost and the annual electricity produced by the wind turbine facility. The annualized cost was estimated considering the capital costs of all the system components and the yearly maintenance cost. (Eq 3) was used to calculate the cost of electricity (COE) (Nouni et al., 2007), where $C_{T}(\$), C_{B}(\$), C_{I}(\$)$ and $C_{C}$

(\$) represent the capital costs of wind turbine including controller and tower, battery bank, inverter and installation and civil works, respectively. $\mathrm{C}_{\mathrm{M}}$ (\$/year) represents the yearly maintenance cost of the system. $R_{T}, R_{B}, R_{I}$ and $R_{C}$ represent the capital recovery factors for wind turbine, battery bank, inverter and civil works, respectively. The yearly electricity production is represented by EL (kWh/year).

$\operatorname{COE}\left(\frac{\$}{\mathrm{kWh}}\right)=\frac{C_{T} R_{T}+C_{B} R_{B}+C_{I} R_{I}+C_{C} R_{C}+C_{M}}{E_{L}}$

Table 4

Key assumptions and technical parameters for the techno-economic modelling

\begin{tabular}{|c|c|c|}
\hline Parameter & Value & Comment/source \\
\hline Interest rate, $\%$ & 10 & $\begin{array}{l}\text { (Md. Mustafizur Rahman et al., } \\
\text { 2016; Zubair et al., 2012) }\end{array}$ \\
\hline Inflation rate, $\%$ & 7.30 & $\begin{array}{c}2014 \text { annual average inflation } \\
\text { rate. Obtained from ("Bangladesh } \\
\text { Bank,") }\end{array}$ \\
\hline \multicolumn{3}{|l|}{ Wind turbine } \\
\hline Rated power, kW & 3.2 & (Nouni et al., 2007) \\
\hline Lifetime, years & 20 & $\begin{array}{c}\text { (Fleck \& Huot, 2009; Nouni et al., } \\
\text { 2007) }\end{array}$ \\
\hline $\begin{array}{l}\text { Capital cost } \\
\text { (including } \\
\text { controller and } \\
\text { tower), } \$ / \mathrm{kW} \\
\text { Lead-acid battery } \\
\text { bank }\end{array}$ & $\begin{array}{c}5030.8 \\
2^{\mathrm{a}}\end{array}$ & $\begin{array}{l}\text { Inflated for the year of } 2015 \\
\text { (Nouni et al., 2007) }\end{array}$ \\
\hline Capacity (each), Ah & 130 & $\begin{array}{l}\text { (Md. Mustafizur Rahman et al., } \\
\text { 2016) }\end{array}$ \\
\hline Nominal voltage, $\mathrm{V}$ & 12 & $\begin{array}{l}\text { (Md. Mustafizur Rahman et al., } \\
\text { 2016) }\end{array}$ \\
\hline $\begin{array}{l}\text { Depth of discharge } \\
\text { (DOD), \% }\end{array}$ & 80 & (Verma et al., 2015) \\
\hline $\begin{array}{l}\text { Charging efficiency } \\
\left(\eta_{c}\right), \%\end{array}$ & 85 & $\begin{array}{l}\text { (Md. Mustafizur Rahman et al., } \\
\text { 2016) }\end{array}$ \\
\hline $\begin{array}{l}\text { Capital cost, \$ (each } \\
130 \mathrm{Ah}, 12 \mathrm{~V} \\
\text { battery) }\end{array}$ & 155.84 & ("BD Stall,") \\
\hline Lifetime, years & 5 & $\begin{array}{c}\text { ("Lead battery recycling in } \\
\text { Banladesh," ; Yang, Wei, \& } \\
\text { Chengzhi, 2009) }\end{array}$ \\
\hline \multicolumn{3}{|l|}{ Inverter } \\
\hline Capital cost, $\$ / \mathrm{kW}$ & 277.08 & $\begin{array}{c}\text { Inflated for the year of } 2015 \\
\text { (Alam Hossain Mondal \& Sadrul } \\
\text { Islam, 2011) }\end{array}$ \\
\hline Lifetime, years & 10 & $\begin{array}{l}\text { (Md. Mustafizur Rahman et al., } \\
\text { 2016) }\end{array}$ \\
\hline \multicolumn{3}{|l|}{$\begin{array}{l}\text { Installation and } \\
\text { civil works }\end{array}$} \\
\hline Capital cost, $\$ / \mathrm{kW}$ & $\begin{array}{c}349.37 \\
\mathrm{~b}\end{array}$ & $\begin{array}{l}\text { Inflated for the year of } 2015 \\
\text { (Nouni et al., 2007) }\end{array}$ \\
\hline $\begin{array}{l}\text { Lifetime of civil } \\
\text { works, years }\end{array}$ & 20 & $\begin{array}{l}\text { (Md. Mustafizur Rahman et al., } \\
\text { 2016) }\end{array}$ \\
\hline $\begin{array}{l}\text { Yearly maintenance } \\
\text { cost, } \%\end{array}$ & 2.0 & $\begin{array}{l}2.00 \% \text { of the total capital cost } \\
\text { (Md. Mustafizur Rahman et al., } \\
\text { 2016; Verma et al., 2015) }\end{array}$ \\
\hline
\end{tabular}




\section{Results and discussion}

\subsection{Techno-economic assessment}

Based on the wind velocity for the location under study a $3.2 \mathrm{~kW}$ wind speed was selected. The wind speed of the island varies from 3.64-7.43 m/s. Using the monthly average wind speeds WEA tool (Bhuiyan et al., 2013) estimates the Weibull shape factor (k) and shape factor (c) as 1.936 and $5.527 \mathrm{~m} / \mathrm{s}$, respectively. The WEA tool also calculates the electrical power generation by the system using the Weibull shape factor, scale factor, rated speed, cut-in speed, cut-out speed and yearly operation hours. The electricity production was estimated to be $6.023 \mathrm{MWh} /$ year using a $3.2 \mathrm{~kW}$ wind turbine. To satisfy the calculated load, three $3.2 \mathrm{~kW}$ wind turbines are required. The total electricity production from three $3.2 \mathrm{~kW}$ wind turbines is 18.07 MWh/year. To store the required electricity battery bank is required. The capacity of battery bank was estimated using (Eq 2). The total battery capacity was estimated to be $8676.46 \mathrm{Ah}$ and to satisfy this capacity a total of sixty seven 130 Ah lead-acid batteries are required. To alter the direct current in to alternating current which is to be fed to the load side a $5.27 \mathrm{~kW}$ inverter is required.

Once the system design was completed to meet the demand of the island, an economic analysis was done to estimate the total capital cost and the COE. Considering $\$ 5030.82 / \mathrm{kW}$ for the wind turbine capital cost of three $3.2 \mathrm{~kW}$ wind turbines was estimated to be $\$ 48,295.824$. At $\$ 155.84 /$ battery, sixty seven batteries (130Ah, $12 \mathrm{~V}$ each) require $\$ 10,441.56$. The capital cost of the inverter and civil works and installation were calculated to be $\$ 1458.81$ and $\$ 3353.97$, respectively. The system's total capital cost was calculated as $\$ 63,550.16$ or BDT 4893362.22. Figure 7 delineates the capital costs of the components of the wind turbine system.

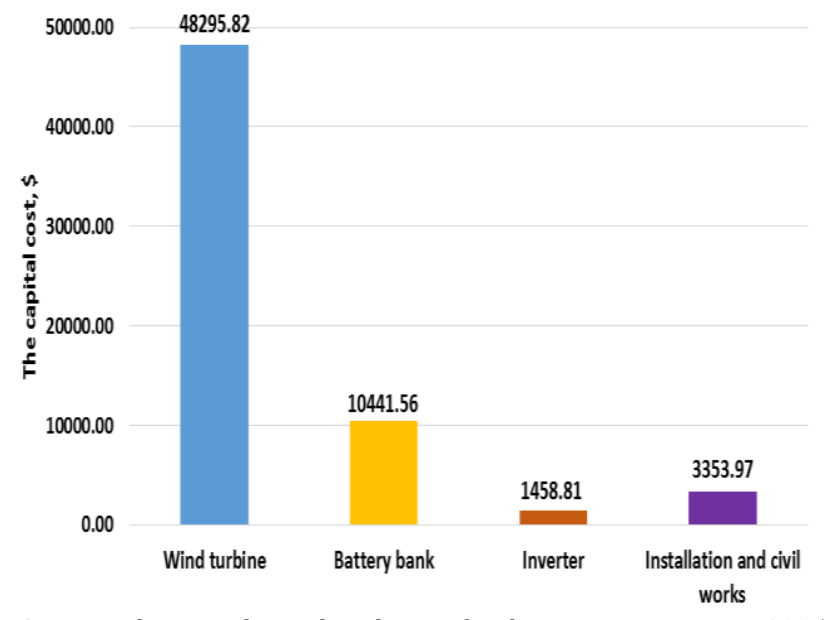

Figure 7 The capital cost distribution for the system. Base year-2015

The amortization of all the capital costs were done over the component's life time using an interest rate of $10 \%$ (see Table 4). Table 5 represents the values of the economic parameters of the system. The total annualized cost was calculated as $\$ 10,329.64 /$ year or BDT 795,382.23/year for the system. Wind turbines and battery bank are the most expensive elements of the system. Figure 8 shows the break-up of the total annualized cost of the system. The capital cost of the wind turbines is the highest but the turbines have a longer lifetime of 20 years. It can be noticed that wind turbines and battery bank contribute 54.92\% and $26.67 \%$ of the total annualized cost followed by yearly maintenance with about $12.30 \%$ (see Figure 8 ). The $\mathrm{COE}$ is the ratio of total annual cost of the system to the total electricity generation by the system. The COE was estimated as $\$ 0.57 / \mathrm{kWh}$ or BDT $44.02 / \mathrm{kWh}$.

Table 5

The annual costs of different components of the system. Base year2015

\begin{tabular}{|c|c|c|}
\hline Parameter & Value & Comment/source \\
\hline $\begin{array}{l}\text { Number of turbines } \\
\text { required }\end{array}$ & 3 & $\begin{array}{l}\text { Calculated from the electricity } \\
\text { requirement of the community } \\
\text { and effective electricity } \\
\text { delivered by one turbine. }\end{array}$ \\
\hline \multicolumn{3}{|l|}{ Annualized cost } \\
\hline Wind turbine, \$/yeara & 5672.81 & $\begin{array}{c}\text { Considering three } 3.2 \mathrm{~kW} \\
\text { turbines }\end{array}$ \\
\hline Battery bank, \$/yeara & 2754.46 & $\begin{array}{c}\text { See (Eq 2) for sizing of battery } \\
\text { bank }\end{array}$ \\
\hline Inverter, \$/year & 237.41 & \\
\hline $\begin{array}{l}\text { Installation and civil } \\
\text { works, \$/yeara }\end{array}$ & 393.96 & \\
\hline $\begin{array}{l}\text { Total maintenance, } \\
\text { \$/year }\end{array}$ & 1271.00 & Refer to Table 4 \\
\hline
\end{tabular}

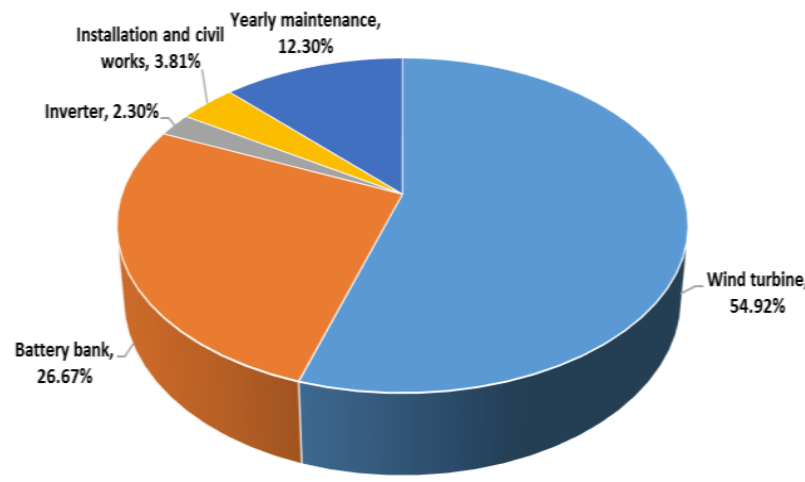

Figure 8 Annual cost break-up of the system

As the system is designed to satisfy the peak summer load there will be some excess electricity that can be used if there is any sudden increase in load demand. 
Citation: Rahman, M.M., Baky, M.A.H., Islam A.K.M.S. (2017), Electricity from Wind for Off-Grid Applications in Bangladesh: A Techno-Economic Assessment. Int. Journal of Renewable Energy Development, 6(1), 55-64, doi.org/10.14710/ijred.6.1.55-64

P a g e 62

The excess power also can be used for satisfying the deferrable loads (Adaramola et al., 2014).

The proposed power generation system is able to generate electricity at a cost of $\$ 0.57 / \mathrm{kWh}$. The COE of the wind-based power generation system was compared with the COE of diesel power generation system. Several research have studied the technoeconomic analysis of power generation from diesel fuel using diesel generators in communities which are not connected to the grid in Bangladesh. Salehin et al. (Salehin et al., 2015) conducted an economic assessment of hybrid system and only diesel generator system for an off-grid community. The authors estimated the COE for diesel generator power production system to be $\$ 0.423 / \mathrm{kWh}$ at a diesel cost of $\$ 0.90 /$ litre. Another study by Shezan et al. (Shezan, Salahuddin, Farzana, \& Hossain, 2016) estimated the COE for diesel generator system as $\$ 0.61 / \mathrm{kWh}$ for the Saint Martin's Island. It can be observed that the COE of the proposed wind power generation system is lower than the COE of the existing diesel-fueled system.

The cost of electricity (COE) of this study was compared with the COE of other earlier studies in the literature for wind power generation system (Ajayi et al., 2014; Genc, 2010; Khadem, 2006; Nouni et al., 2007; Ohunakin, Oyewola, \& Adaramola, 2013). Table 6 shows the comparison of $\mathrm{COE}$ among the studies. The COE estimated in the present study is very close to the range of COEs reported by Khadem (Khadem, 2006). The variation of results among the studies is mainly due to various system boundaries considered in the studies. The other reasons of variation are the scale of operation and various assumptions used in the studies. Usually $\mathrm{COE}$ is low for larger wind turbines and vice versa. Some of the studies do not consider all the system components. Despite of these variations the COE of this study is close enough with the studies in the literature.

Table 6

Comparison of cost of electricity (COE) reported in various studies

\begin{tabular}{|c|c|c|}
\hline Location & $\begin{array}{c}\text { COE } \\
(\$ / \mathbf{k W h})\end{array}$ & Comment/source \\
\hline $\begin{array}{l}\text { Saint Martin's island, } \\
\text { Bangladesh }\end{array}$ & 0.57 & This study \\
\hline $\begin{array}{l}\text { Coastal areas of } \\
\text { Bangladesh }\end{array}$ & $0.31-0.51$ & (Khadem, 2006) \\
\hline $\begin{array}{l}\text { Remote locations of } \\
\text { India }\end{array}$ & $0.10-1.86$ & (Nouni et al., 2007) \\
\hline $\begin{array}{l}\text { Six different cities of } \\
\text { Nigeria }\end{array}$ & $\begin{array}{l}0.129- \\
0.327\end{array}$ & (Ajayi et al., 2014) \\
\hline $\begin{array}{l}\text { Six different cities of } \\
\text { Nigeria }\end{array}$ & $\begin{array}{c}0.0238- \\
7.72\end{array}$ & (Ohunakin et al., 2013) \\
\hline $\begin{array}{l}\text { Five different places in } \\
\text { Turkey }\end{array}$ & $0.09-0.78$ & $\begin{array}{c}\text { Five different capacities of } \\
\text { wind turbine were } \\
\text { considered (Genc, 2010) }\end{array}$ \\
\hline
\end{tabular}

\subsection{Environmental impact assessment}

The renewable energy sources are thought of clean sources of power generation only if greenhouse (GHG) gas mitigation potential is calculated based on the operational phase without considering the upstream stages (i.e. raw material extraction, manufacturing and transportation). This study accounts for GHG emissions from cradle-to-grave life cycle. Life cycle analysis has become a very popular tool to quantify the emissions of GHGs from all the unit operations (e.g. extraction, transportation, end use, etc.) of a product or system (Md Mustafizur Rahman, Canter, \& Kumar, 2014, 2015). A wind turbine power plant emits only $9 \mathrm{~g}-\mathrm{CO}_{2}$ per $\mathrm{kWh}$ of electricity produced (Guezuraga, Zauner, \& Pölz, 2012) on a life cycle basis. The grid emission factor of Bangladesh is $637 \mathrm{~g}-\mathrm{CO}_{2} / \mathrm{kWh}$ (Brander, Sood, Wylie, Haughton, \& Lovell, 2011). Wind turbine plants have a significant potential to reduce GHGs. This study shows how much GHGs can be reduced if conventional power generation systems are replaced by wind power plants. Table 7 shows the emission factors (EFs) of different electricity generation techniques. The wind turbine system produces $18.07 \mathrm{MWh}$ /year of electricity which emits only $162.63 \mathrm{~kg}-\mathrm{CO}_{2} /$ year (there is no operational emissions). With the Bangladeshi national grid emission factor of $637 \mathrm{~g}-\mathrm{CO}_{2} / \mathrm{kWh}$, the wind power plant can mitigate $11,347.96 \mathrm{~kg}-\mathrm{CO}_{2} /$ year if the national grid mix is replaced by wind power generation system. The $\mathrm{CO}_{2}$ mitigation potential of a wind power plant are 8745.88 $\mathrm{kg}-\mathrm{CO}_{2} /$ year, $18,738.59 \mathrm{~kg}-\mathrm{CO}_{2} /$ year and 17,473.69 kg$\mathrm{CO}_{2} /$ year if a wind power plant replaces a gas, coal and oil power plant, respectively. It is not feasible to replace all the conventional power plants with the renewable power plants due to cost and resource availability constraints. But GHG emissions can be reduced significantly by incorporating more renewable based power generation systems in the country's total power generation capacity.

Table 7

Emission factors of different power generation system

\begin{tabular}{|c|c|c|}
\hline $\begin{array}{l}\text { Power generation } \\
\text { system }\end{array}$ & $\begin{array}{l}\text { Emission factor } \\
\left(\mathrm{g}-\mathrm{CO}_{2} / \mathrm{kWh}\right)\end{array}$ & Comment/source \\
\hline Wind turbine & 9 & $\begin{array}{c}\text { (Guezuraga et al., } \\
\text { 2012) }\end{array}$ \\
\hline Bangladeshi grid & 637 & (Brander et al., 2011) \\
\hline Coal power plant & 1046 & $\begin{array}{c}\text { (Guezuraga et al., } \\
\text { 2012) }\end{array}$ \\
\hline Gas power plant & 493 & $\begin{array}{c}\text { Combined cycle power } \\
\text { plant (Ramachandran } \\
\text { Kannan, Leong, Osman, } \\
\text { Ho, \& Tso, 2005) }\end{array}$ \\
\hline Oil power plant & 976 & $\begin{array}{c}\text { (R Kannan, Tso, Osman, } \\
\text { \& Ho, 2004) }\end{array}$ \\
\hline
\end{tabular}




\subsection{Sensitivity analysis}

Sensitivity analysis was performed to observe the impact of different variables on the final results. In this study, seven parameters- interest rate, costs of turbine, battery bank and inverter, lifetime of turbine, battery bank and inverter were varied by \pm 20 to see the impact on the COE. The base-case numbers of these parameters are presented in Table 4 . Figure 9 shows the results of the sensitivity analysis. The COE $(\$ / \mathrm{kWh})$ increases with the increase in the capital cost of wind turbines $(\$ / \mathrm{kW})$. This parameter has the largest influence on the COE (see Figure 9). A 20\% increase in the interest rate increases the COE by $9.79 \%$ because the increased discount rate increases the total cost of the project. The cost of electricity is changed from $\$ 0.54 / \mathrm{kWh}$ to $\$ 0.60 / \mathrm{kWh}$ when the battery bank cost varies to $+20 \%$ from $-20 \%$. The impact of cost of inverter on the COE is negligible as the inverter is the least costly equipment in the system. On the other hand the increased lifetime reduces the COE of the system. The shift in the lifetime of battery bank from 5 years to 6 years results in a $\$ 0.02$ reduction in the COE. The lifetime of the turbine has the similar impact on the COE (see Figure 9).

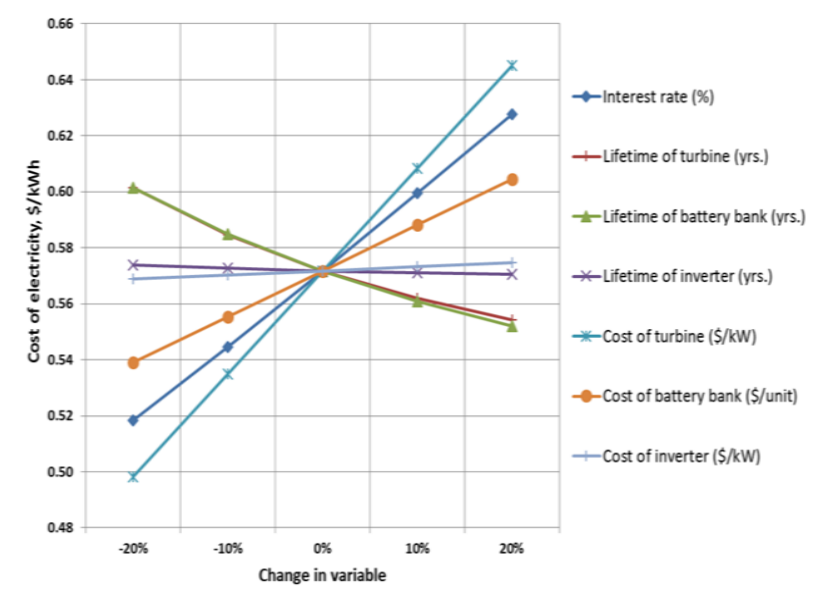

Figure 9 Sensitivity analysis for COE

\section{Conclusions}

The current study estimates the COE for an isolated remote community in the coastal area of Bangladesh through the development of an excel-based technoeconomic model. The model estimates the COE as $\$ 0.57 / \mathrm{kWh}$ or BDT $44.02 / \mathrm{kWh}$ with a capital cost of $\$ 63,550.16$ or BDT $4,893,362.22$. The model also shows that wind turbine is the most costly equipment of the power generation system followed by the battery bank. This study reveals that electricity can be produced at a lower cost with wind energy than diesel generator for the selected location. The electricity generation from wind is not only cost competitive but also environmentally friendly. The proposed electricity generation system from wind could mitigate 17,473.69 $\mathrm{kg}-\mathrm{CO}_{2} /$ year if diesel generator power generation system is replaced by wind power generation system. An analysis was performed to understand the influence of different input parameters on the final results. The sensitivity analysis reveals that the turbine cost is the most dominating factor on the COE. This study will help the government and other policy makers to replace the off-grid diesel generation systems with the wind turbines where there is sufficient wind speed for power generation. The present study will also be helpful for comparing the economics of different renewable power generation technologies.

\section{References}

Abdulkarim, H. (2004). Techno-economic analysis of solar energy for electric power generation in Nigeria: Citeseer.

Adaramola, M. S., Agelin-Chaab, M., \& Paul, S. S. (2014). Analysis of hybrid energy systems for application in southern Ghana. Energy Conversion and Management, 88, 284-295. doi: http://dx.doi.org/10.1016/j.enconman.2014.08.029

Ahammed, S. S., Hossain, M. A., Abedin, M. Z., \& Khaleque, M. A. (2016). A Study Of Environmental Impacts On The Coral Resources In The Vicinity of The Saint Martin Island, Bangladesh. International Journal of Scientific \& Technology Research, 5(1), 37-39.

Ahmed, N. A., Miyatake, M., \& Al-Othman, A. (2008). Power fluctuations suppression of stand-alone hybrid generation combining solar photovoltaic/wind turbine and fuel cell systems. Energy Conversion and Management, 49(10), 2711-2719.

Ajayi, O., Ohijeagbon, O., Aasa, S., \& Omotosho, O. (2014). TechnoEconomic Assessment of Renewable Electricity for Rural Electrification and IT Applications in Selected Sites Across the Geopolitical Zones of Nigeria.

Akpinar, E., \& Akpinar, S. (2006). An investigation of wind power potential required in installation of wind energy conversion systems. Proceedings of the Institution of Mechanical Engineers, Part A: Journal of Power and Energy, 220(1), 1-13.

Alam Hossain Mondal, M., \& Sadrul Islam, A. K. M. (2011). Potential and viability of grid-connected solar PV system in Bangladesh. Renewable energy, 36(6), 1869-1874. doi: http://dx.doi.org/10.1016/j.renene.2010.11.033

American Petroleum Institute. 1999. Basic Petroleum Data Book. Washington (DC): API.

Bangladesh Bank. Retrieved April 14, 2016, from https://www.bb.org.bd/econdata/inflation.php

Bangladesh Power Development Board. Retrieved March 29, 2016, from http://www.bpdb.gov.bd/bpdb/

BD Stall. Retrieved April 14, 2016, from http://www.bdstall.com/listingDetail/index/8342/

Bhuiyan, A., Islam, A., \& Alam, A. (2013). Development of Web Based Wind Resource Assessment (WEA) Tool. Journal of Energy and Environment, 3(1).

Brander, M., Sood, A., Wylie, C., Haughton, A., \& Lovell, J. (2011). Electricity-specific emission factors for grid electricity. Ecometrica. Edinburgh, United Kingdom.

Celik, A. N. (2007). A techno-economic analysis of wind energy in southern Turkey. International Journal of Green Energy, 4(3), 233-247.

Chandel, M., Agrawal, G. D., Mathur, S., \& Mathur, A. (2014). Technoeconomic analysis of solar photovoltaic power plant for garment zone of Jaipur city. Case Studies in Thermal Engineering, 2, 1-7. doi: http://dx.doi.org/10.1016/j.csite.2013.10.002

Chong, W., Naghavi, M., Poh, S., Mahlia, T., \& Pan, K. (2011). Technoeconomic analysis of a wind-solar hybrid renewable energy system with rainwater collection feature for urban high-rise application. Applied Energy, 88(11), 4067-4077.

Dursun, B., Gokcol, C., Umut, I., Ucar, E., \& Kocabey, S. (2013). Technoeconomic evaluation of a hybrid PV-Wind power generation system. International Journal of Green Energy, 10(2), 117-136. 
Citation: Rahman, M.M., Baky, M.A.H., Islam A.K.M.S. (2017), Electricity from Wind for Off-Grid Applications in Bangladesh: A Techno-Economic Assessment. Int. Journal of Renewable Energy Development, 6(1), 55-64, doi.org/10.14710/ijred.6.1.55-64

P a g e 64

Evans, A., Strezov, V., \& Evans, T. J. (2009). Assessment of sustainability indicators for renewable energy technologies. Renewable and Sustainable Energy Reviews, 13(5), 1082-1088.

Fadaeenejad, M., Radzi, M. A. M., AbKadir, M. Z. A., \& Hizam, H. (2014) Assessment of hybrid renewable power sources for rural electrification in Malaysia. Renewable and Sustainable Energy Reviews, 30, 299-305. doi http://dx.doi.org/10.1016/j.rser.2013.10.003

Fleck, B., \& Huot, M. (2009). Comparative life-cycle assessment of a small wind turbine for residential off-grid use. Renewable energy, 34(12), 2688-2696.

Genc, M. S. (2010). Economic analysis of large-scale wind energy conversion systems in central anatolian Turkey. Clean energy systems and Experiences Intech-Sciyo, 131-154.

Ghasemi, A., Asrari, A., Zarif, M., \& Abdelwahed, S. (2013). Technoeconomic analysis of stand-alone hybrid photovoltaic-dieselbattery systems for rural electrification in eastern part of IranA step toward sustainable rural development. Renewable and Sustainable Energy Reviews, 28, 456-462. doi: http://dx.doi.org/10.1016/j.rser.2013.08.011

Guezuraga, B., Zauner, R., \& Pölz, W. (2012). Life cycle assessment of two different $2 \mathrm{MW}$ class wind turbines. Renewable energy, 37(1), 37-44.

GWEC. Global Wind Energy Council. Retrieved April 15, 2016, from http://www.gwec.net/

IDCOL, Infrastructure Development Company Limited. Retrieved March 29, 2016, from http://www.idcol.org/

IEA. Key issues in developing renewable. Paris: International Energy Agency, 1997.

Islam, A. S., Rahman, M. M., Mondal, M. A. H., \& Alam, F. (2012). Hybrid energy system for St. Martin Island, Bangladesh: an optimized model. Procedia Engineering, 49, 179-188.

Kannan, R., Leong, K., Osman, R., Ho, H., \& Tso, C. (2005). Gas fired combined cycle plant in Singapore: energy use, GWP and costlife cycle approach. Energy Conversion and Management, 46(13), 2145-2157.

Kannan, R., Tso, C., Osman, R., \& Ho, H. (2004). LCA-LCCA of oil fired steam turbine power plant in Singapore. Energy Conversion and Management, 45(18), 3093-3107.

Khadem, S. K. (2006). Feasibility study of wind home system in coastal region of Bangladesh. Energy, 4, 5

Khan, F. I., Hawboldt, K., \& Iqbal, M. (2005). Life cycle analysis of wind-fuel cell integrated system. Renewable energy, 30(2), 157177.

Kusakana, K., \& Vermaak, H. J. (2013). Hybrid renewable power systems for mobile telephony base stations in developing countries. Renewable energy, 51, 419-425. doi: http://dx.doi.org/10.1016/j.renene.2012.09.045

Leonoics. $\quad$ Retrieved April 14, 2016, from http://www.leonics.com/support/article2_12j/articles2_12j_en. php

Li, C., Ge, X., Zheng, Y., Xu, C., Ren, Y., Song, C., \& Yang, C. (2013) Techno-economic feasibility study of autonomous hybrid wind/PV/battery power system for a household in Urumqi, China. Energy, 55, 263-272.

Mathew, S. (2006). Wind energy: fundamentals, resource analysis and economics (Vol. 1): Springer.

Muralikrishna, M., \& Lakshminarayana, V. (2008). Hybrid (solar and wind) energy systems for rural electrification. ARPN Journal of Engineering and Applied Sciences, 3(5), 50-58.

Ngan, M. S., \& Tan, C. W. (2012). Assessment of economic viability for $\mathrm{PV} /$ wind/diesel hybrid energy system in southern Peninsular Malaysia. Renewable and Sustainable Energy Reviews, 16(1), 634647. doi: http://dx.doi.org/10.1016/j.rser.2011.08.028

Nouni, M., Mullick, S., \& Kandpal, T. (2007). Techno-economics of small wind electric generator projects for decentralized power supply in India. Energy Policy, 35(4), 2491-2506.

Ohunakin, O. S., Oyewola, O. M., \& Adaramola, M. S. (2013). Economic analysis of wind energy conversion systems using levelized cost of electricity and present value cost methods in Nigeria. International Journal of Energy and Environmental Engineering, $4(1), 1-8$.
Pimentel, D., Herz, M., Glickstein, M., Zimmerman, M., Allen, R., Becker, K., Grosfeld, A. (2002). Renewable Energy: Current and Potential Issues Renewable energy technologies could, if developed and implemented, provide nearly $50 \%$ of US energy needs; this would require about $17 \%$ of US land resources. Bioscience, 52(12), 1111-1120.

Power Division. Government of The People's Republic of Bangladesh. Retrieved March 29, 2016, from http://powerdivision.gov.bd/

Rahman, M. M., Canter, C., \& Kumar, A. (2014). Greenhouse gas emissions from recovery of various North American conventional crudes. Energy, 74, 607-617.

Rahman, M. M., Canter, C., \& Kumar, A. (2015). Well-to-wheel life cycle assessment of transportation fuels derived from different North American conventional crudes. Applied Energy, 156, 159-173.

Rahman, M. M., Islam, A. K. M. S., Salehin, S., \& Al-Matin, M. A. (2016). Development of a Model for Techno-economic Assessment of a Stand-alone Off-grid Solar Photovoltaic System in Bangladesh. International Journal of Renewable Energy Research-IJRER, 6(1), 140-149.

Rahman, M. M., Khan, M. M.-U.-H., Ullah, M. A., Zhang, X., \& Kumar, A. (2016). A hybrid renewable energy system for a North American off-grid community. Energy, 97, 151-160. doi: http://dx.doi.org/10.1016/j.energy.2015.12.105

Rehman, S., \& Al-Hadhrami, L. M. (2010). Study of a solar PV-dieselbattery hybrid power system for a remotely located population near Rafha, Saudi Arabia. Energy, 35(12), 4986-4995. doi: http://dx.doi.org/10.1016/j.energy.2010.08.025

REN21. Renewables 2015 Global Status Report. Retrieved April 14, 2016, from http://www.ren21.net/wpcontent/uploads/2015/07/REN12 GSR2015_Onlinebook low1.pdf

Rohani, G., \& Nour, M. (2014). Techno-economical analysis of standalone hybrid renewable power system for Ras Musherib in United Arab Emirates. Energy, 64, 828-841. doi: http://dx.doi.org/10.1016/j.energy.2013.10.065

Saint Martin Coral Island, Bangladesh. Retrieved April 14, 2016, from http://aboutbangladesh71.blogspot.com/2013/08/saintmartin-coral-island-bangladesh.html

Salehin, S., Rahman, M. M., \& Islam, A. S. (2015). Techno-economic Feasibility Study of a Solar PV-Diesel System for Applications in Northern Part of Bangladesh. International Journal of Renewable Energy Research (IJRER), 5(4), 1220-1229.

Shezan, S., Salahuddin, A., Farzana, M., \& Hossain, A. (2016). Technoeconomic analysis of a hybrid $P V$-wind-diesel energy system for sustainable development at coastal areas in Bangladesh. Paper presented at the 2016 4th International Conference on the Development in the in Renewable Energy Technology (ICDRET).

Sopian, K., Ali, Y., Alghoul, M. A. M. D., Zaharim, A., \& Ahmad, I. (2009) Optimization of PV-wind-hydro-diesel hybrid system by minimizing excess capacity. European Journal of Scientific Research, 25(4), 663-671.

Surface meteorology and solar energy. Retrieved April 14, 2016, from https://eosweb.larc.nasa.gov/sse/.

Sustainable \& renewable energy energy development authority (SREDA). Retrieved April 14, 2016, from http://www.sreda.gov.bd/.

The world Bank. Retrieved March 29, 2016, from http://data.worldbank.org/indicator/EG.USE.PCAP.KG.OE

Turner, J. A. (1999). A realizable renewable energy future. Science, 285(5428), 687-689.

Verma, A., Raj, R., Kumar, M., Ghandehariun, S., \& Kumar, A. (2015). Assessment of renewable energy technologies for charging electric vehicles in Canada. Energy, 86, 548-559.

Yang, H., Wei, Z., \& Chengzhi, L. (2009). Optimal design and technoeconomic analysis of a hybrid solar-wind power generation system. Applied Energy, 86(2), 163-169. doi: http://dx.doi.org/10.1016/j.apenergy.2008.03.008.

Zubair, A., Tanvir, A. A., \& Hasan, M. M. (2012). Optimal planning of standalone solar-wind-diesel hybrid energy system for a coastal area of Bangladesh. International Journal of electrical and computer engineering, 2(6), 731. 